\title{
Az állam általános elmélete és a jog viszonylagos ereje - Észrevételek Georg Jellinek államelméletéhez
}

\begin{abstract}
Georg Jellinek - Paul Laband - államelmélet - jogászi módszer - általános államtan - alkotmányos monarchia - az állam személyisége - a ténylegesség normatív ereje - az állam kétoldalúságának elmélete - az önkötelezés elve
\end{abstract}

Azok az intézményrendszerbeli változások, amelyek a nemzeti jogrendszerek európaizálódásával és nemzetköziesedésével jártak, az állam- és jogelméleti diskurzus reneszánszát hozták el. Ezeknek a változásoknak a fényében ma már konszenzus van abban, hogy a pozitív jogra és a bírósági ítéletek gondos értelmezésére koncentráló dogmatikus tudás nagyon sok esetben erősen rá van utalva az általános fogalmakat tisztázó és megalapozó, elveket igazolni tudó elméleti tudásra. A joggyakorlat egyre komplexebb problémáit nem lehet csupán a bíróságok által értelmezett fogalmi keretekre támaszkodva megérteni és érthetővé tenni. Ennek a változásnak a legfontosabb határtapasztalata Németországban a német alkotmánybíróság ún. Maastricht-döntése volt. ${ }^{1} \mathrm{~A}$ második világháború után a német közjogtudományt az alkotmánybíróság döntéseiböl kibontakozó dogmatikai elméletek határozták meg. A jogtudósok munkássága többnyire kimerült a bíróság gyakorlatának rekonstrukciójában, kibontásában és értelmezésében. A döntéseket kísérő állandó viták dacára a bíróság szakmai autoritását nem kérdőjelezték meg. A jogtudományi diskurzust az alkotmánybíróság gyakorlata irányította. ${ }^{2}$ A Maastricht-döntést övező viták azonban világossá tették, hogy az az elméleti keret, amelyre a bíróság a döntését alapozta, alapvető korrekcióra szorul. Az állam, az alkotmány, illetve a demokrácia bevett fogalmainak és az európai együttmüködés egyre szilárdabb intézményrendszerének a viszonya a jogi és politikai fogalmak olyan átfogó felülvizsgálatát igényli, amely már (újra?) a jogtudomány kezdeményező szerepét igényli. Ennek az egyik következménye a kilencvenes évek második felétől az egyre intenzívebb érdeklődés az államelmélet és a közjog általános megalapozási kérdései iránt Németországban.

* Dr. Sólyom Péter egyetemi tanársegéd, Debreceni Egyetem Állam- és Jogtudományi Kar Jogbölcseleti és Jogszociológiai Tanszék, solyom.peter@law.unideb.hu.

1 BVerfGE 89, 155. Lásd ehhez magyarul: Paczolay Péter (szerk.): Az alkotmányelmélet és az európai integráció. Budapest, Szent István Kiadó, 2004.

2 ScHLINK, Bernhard: Die Entthronung der Staatsrechtswissenschaft durch die Verfassungsgerichtsbarkeit, Der Staat (1989), 2. sz., 161-172. 
Ebben az élénkülö államelméleti diskurzusban Georg Jellinek elméletének az újraértelmezése megkerülhetetlenné vált. Elmélete a jogtudományt érintő mai kérdésfelvetések kiindulópontját jelenti. Az európai intézményrendszer változását értelmezni akarók nem tudtak szabadulni az általa alkotott fogalmaktól. ${ }^{3}$ Jellinek munkássága a magyar államelméleti diskurzus újraéledésében is fontos szerepet játszott. Takács Péter tankönyveinek szemléletét a mai napig meghatározzák müvei. ${ }^{4}$

Ebben a tanulmányban Jellinek államelmélete legfontosabb kérdéseinek a bemutatására teszek kísérletet. Ennek során kettős célkitűzést követek: egyfelől igyekszem igazolni, hogy miért lehet gyümölcsöző a mai államelméleti viták számára Jellinek elméletének újraértelmezése, másfelöl a magyar Jellinek-értelmezések hangsúlyait próbálom módosítani azzal, hogy Jellinek elméletének gyakorlati vonatkozásaira nagyobb hangsúlyt helyezek, és államelmélete központi kérdésének a politikához való reflexív viszony problémáját teszem.

Jellinek elmélete Laband államjogi pozitivizmusának kritikájából merítette a módszertani energiáit, így az első fejezetben a Laband-kritika jelentőségét próbálom bemutatni. Ezt követően az állam kétoldalú elméletének legfontosabb elemeire térek rá, és igyekszem feltárni azok feloldhatatlannak tűnő ellentmondásait is. A dolgozat harmadik részében a jellineki államelmélet gyakorlati vonatkozásaira próbálom irányítani a figyelmet: milyen mértékben határozta meg az elméletet az, hogy egy alkotmányos monarchia közjogi gyakorlata képezte az elsődleges kontextusát? Végül összefoglalom, mire jutottam.

\section{Jellinek viszonya a labandi jogászi módszerhez}

Jellinek Laband követőjeként vált a századforduló meghatározó államjogászává, elfogadva és tovább építve annak az állam személyiségére épülő jog- és törvényfelfogását: „Az állam egy önálló akarati szubjektum.” Ám az államelmélet módszertani felfogásában és az alkotmányos monarchia értelmezésében, különösen annak a joghoz és néphez való viszonyában jelentős hangsúlyváltást hajtott végre.

Laband a császárság legbefolyásosabb német közjogászának számított. Elképzelései két okból voltak sikeresek. Egyfelöl a közjogtudomány addigi meglehetősen bizonytalan státuszának szilárd alapot adott. Másfelöl a Laband által képviselt konzervatív alkotmányos program nagyon jól illeszkedett a Bismarck-éra alkotmányos gyakorlatához, amely a polgárok nem politikai szabadságjogait védte, és az állam-

3 Lásd különösen BogDANDY, Armin von: Die Europäische Union als supranationale Föderation. In: Integration 22. (1999), 95-112.; BogDANDY, Armin von: Beobachtungen zur Wissenschaft vom Europarecht, Der Staat (2001), 1. sz., 3-43. Lásd erröl még KERSTEN, Jens: Warum Georg Jellinek? Jellinek und die Staats- und Europarechtslehre der Gegenwart. In: AnTER, Andreas (Hrsg.): Die normative Kraft des Faktischen. Das Staatsverständnis Georg Jellineks. Baden-Baden, Nomos, 2004, 185.

4 TAKÁcs Péter: Államtan. Négy fejezet az állam általános elmélete köréből. Az állam általános sajátosságai. Budapest, BCE KIK, 2011; TAKÁcs Péter: Államtan. Két fejezet az állam általános elmélete köréböl. A modern állam és elmélete. Budapest, BCE KIK, 2011. 
hatalmat kizárólag a monarchikus kormányzat kezébe helyezte. Ez az időszak volt az államjogi pozitivizmus, egy nemzeti bürokrata-konzervativizmus időszaka. ${ }^{5}$

Laband államelméletének három fontos alappillére van: (1) a magánjogtudomány módszertani modelljét követő jogászi módszer, (2) a történeti iskola népfelfogása és (3) az alkotmányos monarchia konzervatív értelmezése. Laband Gerberrel ellentétben már egy müködő egységes német állam teoretikusa, egy létező gyakorlatot értékelő közjogtudós.

A jogtudomány feladata a fennálló jog magyarázata - ez volt Laband felfogásának a kiindulópontja. Az érvényes jog magyarázatához szükséges dogmatikai munka három részre bontható: egyfelől jelenti a jogszabályok összegyűjtését és szisztematikus rendjét, másfelől tiszta logikai műveletekkel jogintézmények konstruálását és a jogszabályok visszavezetését általános fogalmakra, végül pedig ezeket a fogalmakat kell továbbgondolni és levezetni a belölük fakadó következményeket. Ez az utolsó mozzanat juttatja kifejezésre a jogtudomány alkotó feladatát. ${ }^{6}$

Laband felfogásában tehát a közjogi dogmatika rendszerét az általános fogalmakból levezetett gondolatmenetek töltik ki tartalommal, és ezen fogalommeghatározások segítségével kell rendet tenni a tételes jog szabályai között. Gerber még egy olyan, a fogalmi konstruktivizmusra épülő közjogtudományt alakított ki, amely meglehetősen lazán kötődött egy adott jogrendszerhez, és inkább a jog-összehasonlításon alapuló tételes jogi munkának tekinthető. Laband műve ezzel szemben egy adott jogrendszer, a Német Birodalom jogrendjének közjogi alapjait kívánta tudományos igénnyel rendszerbe foglalni. Ennek a rendszeralkotásnak volt az eszköze a logikai műveletekre épülő jogászi módszer.

A jogászi módszer a gerberi mintán alapult, legfontosabb mozzanata pedig a jogintézmények konstruálása és azok visszavezetése bizonyos általános fogalmakra. Maga a konstrukció ebben az összefüggésben egy tisztán logikai múveletet jelentett.

5 SchönBerger, Christoph: Ein liberaler zwischen Staatswille und Volkswille. In: Paulson, Stanley - Schulte, Martin: Georg Jellinek: Beiträge zu Leben und Werk. Tübingen, Mohr Siebeck, 2000, 6-7.

6 "Die wissenschaftliche Aufgabe der Dogmatik eines bestimmten positiven Rechts liegt aber in der Construction der Rechtsinstitute, in der Zurückführung der einzelnen Rechtsätze auf allgemeine Begriffe und andererseits in der Herleitung der aus diesen Begriffen sich ergebenden Folgerungen. Dies ist, abgesehen von der Erforschung der geltende positiven Rechtsätze, d.h. Vollständige Kenntnis und Behersschung des zu bearbeitenden Stoffes, eine reine logische Denkthätigkeit. Zur Lösung dieser Aufgabe giebt es kein anderes Mittel als die Logik." Laband, Paul: Staatsrecht des Deutschen Reiches. Freiburg-Leipzig, Mohr, 1895. 3. Auflage; I. Band, X.

„Das Staatsrecht kann nicht mit anderen Mitteln erforscht werden, wie die übrigen Theile der Rechtordnung, namentlich das Privatrecht; es gibt dafür keine andere Methode als die juristische, d.h. Die Abstraction der zugrundeliegenden Prinzipien von positiv geltenden Rechtsätzen und die Deduktion der Folgerungen, welche sich aus den so gefundenen Prinzipien ableiten lassen. Diese geistige Thätigkeit vollzieht sich nach den Grundsätzen der Logik. Die juristische Methode ist gleichbeteund mit der logischen. Allerdings kann sich die Logik den Stoff, mit dem sie operiert, nicht selbst schaffen, sondern er muß ihr gegeben werden. Die Gesetze, das Gewohnheitsrecht und die Praxis der Behörden und anderer Staatsorgane sind die Fundquellen dafür. Aber die geistige Ordnung und wissenschaftliche Beherrschung dieses Materials kann nur mittels logischer Denkoperationen erfolgen." LABAND, Paul: Vorlesungen. BArch. N 2161/l, BI. 8/8R., idézi: ScHLÜTER, Bernd: Reichswissenschaft. Staatsrechtslehre, Staatstheorie und Wissenschaftspolitik im Deutschen Kaiserreich am Beispiel der Reichsuniversität Straßburg. Frankfurt am Main, Vittorio Kostermann, 2004, 342-343. 
De mint általában a logikában, a következtetések helyességét a műveletek helyes használata még nem garantálja. Laband elméletének is ez a leggyengébb pontja. Honnan jönnek ezek az általános fogalmak? Miért éppen ezeket a fogalmakat kell kiindulópontként választanunk? Ezeknek a kérdéseknek a semlegesítésére törekedve társult a logikai múveleteken alapuló jogászi módszerhez a politikamentesség eszméje. Jogtudománynak addig csak a magánjog számított, a közjogi kérdéseket a napi politikai viták esendő területéhez kapcsolták. Laband törekvése az volt, hogy eltávolítsa a közjogtudomány kérdéseit a napi politikai vitáktól és a magánjog mintájára a jogtudomány részévé tegye, amihez a magánjogtól kérte a segítséget. Így a közjogtudomány általános fogalmai elsősorban a magánjogi dogmatikából származtak.

A politikamentesség elve azonban nem elsősorban a modern tudományosság elvárásainak a teljesítéséről szólt. A politikamentesség a fennálló jogrendnek az elfogadását és erősítését is jelentette. A parttalan pártpolitikai viták elutasítása azzal a konzervatívok körében általánosan osztott meggyőződéssel is párosult, amely az állam felemelkedését a meddő vitákon felülemelkedni tudó erős uralkodó intézményében látta. ${ }^{7}$ Laband ebben is Gerber irányát követte, aki szintén azt képviselte, hogy a parlament intézményének a meghonosítása Németországban csak nyugtalanságot eredményezett. ${ }^{8} \mathrm{~A}$ politikamentesség elve tehát a pártpolitikai viták és ezentúl a parlamentarizmus elutasítását is jelentette. Ez együtt járt a Németországban 1849 előtt még különösen népszerủ hatalommegosztás eszméjének elutasításával is. ${ }^{9}$

Ennek a konzervatív szemléletnek az a meggyőződés szolgált az alapjául, hogy a természetjogi ihletettségủ alapjog- és demokráciaelméletek kudarcot vallottak. A monarchia intézményének központba álítása egy realista helyzetértékelés eredménye: tartós és stabil politikai hatalmat csak egy olyan alkotmányos monarchia keretében lehet gyakorolni, ahol az uralkodó személyesíti meg az államhatalom egységét. Ez a fajta realizmus szintén a közjogtudomány önállóságát és tekintélyét növelte. Az alkotmányos monarchia intézménye egyszerre tünt kívánatos és az egyedüli reális lehetőségnek. A közjogtudomány nemcsak a politikai vitákon kívánt felülemelkedni, hanem általában a politikai szempontokon is. ${ }^{10}$

Ezek a körülmények tehát azt erösítették, hogy Laband a politikai összefüggéseket háttérbe szorítva, azokat elnyomva a magánjogi dogmatikát tette a közjogtudomány követendő modelljévé. A magánjogból származó olyan általános fogalmak, mint pl. a személy vagy a társaság fogalmai a közjogtudomány a priori fogalmaivá váltak, és kiválóan alkalmasak voltak arra, hogy a dogmatikai fogalomrendszer alakítójának előzetes politikai döntéseit elleplezzék.

Jellinek szakított a jogászi módszer fenti elgondolásával, elvetette Laband magánjogi ihletettségủ spekulatív fogalomalkotási stratégiáját, és a módszertan alaposabb

7 „In Deutschland beruhen die Parteigegensätze vorzugsweise auf der Feinsdschaft der Stände... Bei solchen Verhältnissen ist ein strakes Königthum ein dringendes Bedürfnis, welches über den Ständen steht, sie gegeneinander schützt und die gegenseitige Bekämpfung und Vernichtung derselben verhütet." LABAND, Paul: Vorlesungen. BI, 362 R., idézi: SchLÜTER: i. m., 349.

8 „Die Einführung der Parlamente in Deutschland habe zu einem System der Unruhe geführt.” Gerber, Carl Friedrich: Über öffentliche Rechte. 1852, Nachdruck, 1968, 80., idézi: ScHLÜTER: i. m., 350.

9 SCHLÜTER: i. m., 349.

10 SCHLÜteR: i. m., 349-350. 
filozófiai megalapozására törekedett. A magánjogi dogmatika helyett az alkotmányos jog-összehasonlítás, a formálódó szociológia szempontjai és az újkantiánus ismeretelmélet vezérelték Jellineket módszertani felfogásának a kialakítása során.

Nem kevésbé jelentősek azok az új hangsúlyok, amelyek Jellinek alkotmányos monarchia értelmezésének különbségeit jelzik Laband felfogásához képest. Míg Laband a birodalom alapítását és az alkotmányos monarchia intézményrendszerét abszolutisztikus irányba továbbértelmező konzervatív teoretikus volt, addig Jellinek - a birodalom feltétlen híveként - annak szabadságkiterjesztő és demokrácia iránt érzékenyebb újraértelmezésén fáradozott. Ő már az alkotmányos monarchia válságának teoretikusa, amikor már egyáltalán nem magától értetődő és elfogadott a monarchikus elv elsőbbsége a népszuverenitás elvével szemben.

Az általános választójog, a szerveződő tömegpártok és érdekképviseletek egyre népszerübbé és elismertebbé váltak az 1890-es években. Ebben az időszakban az az elképzelés, hogy a társadalmat az uralkodó bürokratikus államhatalma fogja öszsze a polgárok egymástól jól elkülönült magánszférájának védelmére hagyatkozva, már erősen vitatott elképzelésnek bizonyult. A birodalomban ekkor már egyaránt beszéltek a nemzet egészét képviselő császárról és a „Reichstag” megnövekedett alkotmányos tekintélyéröl. Az utóbbi jellemzően nem a képviseleti elv elismerésének a következménye, hanem a centralizáció politikájának megfelelően a tartományi parlamentek háttérbe szorításáról szólt. A demokratikus igények kielégítésének terepét a parlamenten kívül keresték és találták meg az érdekképviseletek személyében. Jellinek legfontosabb államelméleti alapfogalmai erről a változásról tanúskodnak. Az „állam önkötelezésének tana” már a jog és az állam új viszonyáról árulkodik, a nép fogalmának visszaemelése az államjogba pedig a demokrácia kérdéseinek a megtárgyalását tette lehetővé. ${ }^{11}$ Ezek a változások nem jelentik azt, hogy Jellinek megtagadta volna az alkotmányos monarchia alapvetően etatista államfelfogását. $A z$ államhatalom egységének elve - az ebben rejlő minden módszertani nehézséggel és nem kevés ellentmondással együtt - a nép egységén alapuló elképzeléssel egészült ki.

\section{Az állam kétoldalúságának elmélete}

Laband államjogi felfogásának kiindulópontja az volt, hogy az állam jogtudományi felfogásából ki kell zárni minden olyan szempontot, amely túlmutat az éppen érvényes államjogi normák értelmezésén. Jellinek nem osztotta ezt az álláspontot. Egyet nem értését az állam kétoldalúságának elmélete fejezte ki. Megkülönböztette az államot mint társadalmi és mint jogi jelenséget. „Az államtannak az államot minden lényeges oldalról vizsgálnia kell. Két fö területe van annak a két szempontnak megfelelöen, amelyből az állam vizsgálható. Az állam ugyanis egyrészt társadalmi képződmény, másrészt jogintézmény. Ennek megfelelően az államtan társadalmi államtanra és államjogtanra oszlik. Eszerint az általános államtannak két része van: az állam álta-

11 SCHÖNBERGER (2000): i. m., 5-11. 
lános társadalomtana és az általános jogtan."12 A társadalmi és jogi államtan szembeállítása a két területen uralkodó módszerek különbségén alapult. Jellinek úgy vélte, hogy a labandi jogászi módszer csak az államjogtan tételeinek megállapításával és e jogtételek tartalmának a fejlődésével kapcsolatban érvényesül, ezért az államjogtan normáit élesen el kell választani az államnak mint társadalmi jelenségeknek a létezésére vonatkozó tételeitől. Jellinek tehát nem felülvizsgálja és kritizálja a jogászi módszert, hanem a helyiértékét változtatja meg az államelméleten belül. ${ }^{13}$ A jogászi módszer jogtudományi használatát tekintve továbbra is a labandi elmélet képviselője maradt. Nem titkolta azonban, hogy a jogászi módszer továbbfejlesztésre szorul, „alkalmazkodnia kell a közjog sajátosságaihoz. A jogi ugyanis nem azonosítható a magánjogival. Bizonyosan módszertani hibát jelent magánjogi fogalmaknak kritika nélküli átvitele a közjog területére, noha kétségtelenül vannak általános jogi formák, amelyek minden jogterület számára közösek."14

Az állam kétoldalúságának az elmélete tehát elsősorban Laband államfelfogásának az újragondolására irányul, nem pedig a közjogtudományban használt jogászi módszer átfogó kritikájára. Laband államjogi nézeteinek tévedései, egyoldalúsága és ellentmondásossága elsősorban arra vezethető vissza, hogy „azokat helytelenül vagy nem kielégítő módon bizonyos államtani tételekre vezették vissza". ${ }^{15}$ Éppen ezért vélte Jellinek - egy átfogó államtanra van szükség, a társadalmi államtan és az államjogtan összefüggésének felismerésére, e nélkül ugyanis szükségképpen tévedések áldozata lesz minden vizsgálódás, ugyanis az állam jogi oldalának alaposabb vizsgálata nem nélkülözheti annak átfogó vizsgálatát. ${ }^{16}$ Jellinek arra hívja fel a figyelmet, hogy a jogászi módszer egyedül nem alkalmas az állam sajátosságainak a megértésére. „Az államtan tudományos meghatározása során nem szabad tehát összekeverni a jogit azzal, ami a jogot megelözi."”17

Az állam kétoldalúságának elmélete tehát a labandi elmélet „valóság-deficitjét” akarja orvosolni, és eközben megfogalmazza a közjogtudomány legnehezebb és ebből fakadóan legtermékenyebb kérdéseit: hogyan lehet megragadni a tartható és helyes normatív állítások empirikus előfeltételeit? Milyen szerepe van az empirikus viszonyoknak a normatív viszonyok létrejöttében? Jellinek az állam kétoldalúságának elméletével a hatalom és a jog viszonyait kívánta egy átfogó elméleti keretben megragadni. Milyen módszertani keretben lehet a normatív és az empirikus összefüggésekre egyaránt tekintettel lenni? ${ }^{18}$

12 JeLLINEK, Georg: Általános államtan. Budapest, ELTE ÁJK, 1994, 28-29.

13 A módszerrel kapcsolatos kritikátlanságát jól jelzi a következő idézet: A jogászi módszer „a jogi normák dogmatikai tartalma tekintetében alkalmazható a jogi jelenségekből nyert absztrakciónak és az így létrejött normákból való dedukciónak kizárólag a jogászok által gyakorolt művészete. Ez a jogi dogmatika másfajta tudománnyal nem pótolható." JelLINEK (1994): i. m., 55.

14 JeLLINEK (1994): i. m., 55.

15 JeLLineK (1994): i. m., 29-30.

16 JeLlineK (1994): i. m., 29-30.

17 JeLLineK (1994): i. m., 29.

18 Ezért nevezte Christoph Möllers Jellineket az „is-is” államelmélet képviselőjének. MöLLERs, Christoph: Skizzen zur Aktualität Georg Jellineks. Vier theoretische Probleme aus Jellineks Staatslehre in Verfassungsrecht und Staatstheorie der Gegenwart. In: PAULSON, Stanley - Schulte, Martin: Georg Jellinek: Beiträge zu Leben und Werk. Tübingen, Mohr Siebeck, 2000, 155. 
A módszertudatosság távol állt Labandtól, nemhiába tekintette Jellinek Gerbert mesterének, Laband inkább csak egy termékeny ellenpontja volt elméleti törekvéseinek. ${ }^{19}$ Gerber idejében a jogtudomány múvelésének meghatározó mintája a természettudományi módszer volt. A természettudományok által használt empirikus oksági törvényszerüségekre koncentráló módszertan nemcsak a szociológiára, hanem a jogtudományra is hatást gyakorolt. Gerber jogászi módszere is sok ihletet merített belőle. Ez az ideál nagyban hozzájárult ahhoz, hogy a jogtudományban is elterjedjen a módszertudatosság igénye, és a racionalitás eszménye elősegítse a fogalomalkotás következetességét és rendszerszerüségét. Ennek az empirikus módszertannak a sikeressége azon múlt, vajon sikerül-e igazolni, hogy a természettudományok és a szellemtudományok tárgyai ugyanolyan létmóddal rendelkeznek, és ennek következtében megragadhatók-e azonos megismerési módszerekkel. ${ }^{20} \mathrm{Az}$ újkantianizmus az empirizmussal folytatott vitából formálódott ki, de századvégi sikerét az akadémiai filozófiában elsősorban a politikai körülményeknek köszönhette. ${ }^{21}$

Az 1848-as forradalom bukása után a politikai filozófiával és a szociális kérdésekkel foglalkozó filozófusokat száműzték az egyetemekről. A konzervatív hegeliánusokon kívül a politikailag semlegesnek ítélt ismeretelmélet müvelői maradhattak csupán a katedrák közelében, akiket később a természettudományos világkép optimizmusát osztók és a kereszténység elveit védelmezők közötti ún. materializmus-vita további megosztottsággal sújtott. E meddő vitákhoz képest a kanti filozófia felé nyitás egy ideális szellemi menedéknek bizonyult. Az újkantiánus bölcselet kezdeti népszerüsége tehát sokat köszönhetett annak, hogy a hivatásos filozófusok számára az 1850-es években komoly egzisztenciális fenyegetettséget jelentett, ha a politikai és a gyakorlati filozófia kérdéseivel foglalkoztak, azokból az akadémiai vitákból pedig, amelyekre még lehetöség volt, nem sok szellemi inspirációt lehetett meríteni. ${ }^{22}$

A politikai összefüggések mellett azonban annak is hatása volt a hegelianizmus hanyatlására, hogy az egyre népszerübb természettudományos világkép sokkal inkább talált fogódzókat Kant ismeretelméletében, mint Hegel spekulatív természetfilozófiájában. ${ }^{23}$ Kant ugyanis „világosan különválasztotta a megismerés területét a vallásosmorális szférától" ${ }^{24} \mathrm{Az}$ újkantianizmus a nyolcvanas évekre a kezdeti óvatos kritikai alapállásból egy olyan meghatározó irányzattá vált, amely meglehetősen apolitikusan viszonyult a reálpolitikai adottságokhoz. ${ }^{25}$

Jellinek az újkantiánus szemléletböl következő belátásait elöször a közjogi jogosultságok rendszeréről írott munkájában fejtette ki. Ebben már az első oldalakon rögzíti, hogy a jogi fogalmak nem a természeti létezőkre és azok törvényszerüségei-

19 KeRsten, Jens: Georg Jellinek und die klassische Staatslehre. Tübingen, Mohr Siebeck, 2000.

20 Lepsius, Oliver: Georg Jellineks Methodenlehre im Spiegel der zeitgenössischen Erkenntnistheorie. In: Paulson, Stanley - Schulte, Martin: Georg Jellinek: Beiträge zu Leben und Werk. Tübingen, Mohr Siebeck, 2000, 310-312.

21 PAscher, Manfred: Az újkantianizmus gyakorlati filozófiája. Debrecen, Latin betűk, 1996, 22-33.

22 PASCHER: i. m., 23-24.

23 PASCHER: $i$. m., 26.

24 PASCHER: i. m., 26.

25 PASCHER: i. m., 32. 
re irányulnak, hanem esztétikai ítéletekhez hasonlatos absztrakciók. ${ }^{26}$ Ahogyan a zenetudományban a szimfónia fogalma sem a rezgésszámok és a levegőt alkotó részecskék mozgásának a függvénye, a jogászok világában is a jogi fogalmak az emberi cselekvésekre vonatkoznak, olyan dolgokra, amelyek értünk vannak és nem önmagukban állnak. ${ }^{27} \mathrm{~A}$ tulajdon és a birtok, a vétel és a bérlet, a házasság és az örökség nem megfogható és látható dolgok, hanem olyan komplex viszonyrendszerek, amelyeket csak absztrakt fogalmakon keresztül lehet megragadni. Jellinek szerint elsősorban az emberi célokra tekintettel. ${ }^{28} \mathrm{~A}$ jogászok feladata nem az, hogy például a tulajdon jogintézményéhez kapcsolódóan az emberi megismerés minden pszichológiai összefüggését számításba vegyék, hanem csupán annak tisztázása, hogyan kell a tulajdon intézményét elgondolnunk ahhoz, hogy az ezzel összefüggésbe hozható normák egy ellentmondásmentes rendszert alkothassanak ${ }^{29}$ Jellinek szerint tehát a jog fogalmai absztrakciók, de olyan absztrakciók, amelyek a létezőkre vonatkoznak (tehát nem fikciók). A jog normatív természetének megalapozott ténybeli vonatkozások nélkül nincs értelme.

Ebben az összefüggésben van jelentősége annak, hogy az állam egyfelöl egy reális adottság, másfelöl pedig egy jogászi absztrakció. Jellinek az egyéni közjogi jogosultságok rendszerének összefoglalása során még csak az állam jogi oldalának jellegzetességeit hangsúlyozta. A kettő közötti összefüggések tárgyalása volt az általános államtan központi témája.

A társadalomtudományi megismerés további jellegzetessége, hogy elsősorban individuumok teljesítményein alapul. Éppen ezért a társadalomtudósok nem rendelkeznek olyan általános törvényekkel, mint a természettudósok. Ezen a területen „az általános törvények rendszerint bizonytalan elöfeltevéseken és a tények nem kielégítő ismeretén alapuló konstrukciókon nyugszanak" ${ }^{30} \mathrm{Az}$ emberi teljesítmények a természeti erők egyformaságával szemben végtelenül sokfélék, „egyetlen társadalmi esemény sem puszta reprezentánsa egy fajnak (mint gyüjtőfogalomnak), hanem egyben valami csak egyszer és itt létező, sohasem pontosan ugyanabban a formában visszatérö" ${ }^{31}$ Jellinek a jogi absztrakciókat éppen ezért egyfajta típusalkotásként fogta fel. Az empirikus típus fogalma fejezte ki ezt a törekvést, amely a jelenségek jellemző ismérveinek a kutató által elfoglalt nézőpontból való összefoglalását jelentette. ${ }^{32} \mathrm{Az}$ „empirikus” ebben az összefüggésben azt juttatja kifejezésre, hogy nem

26 „Die juristischen Begriffe haben daher keine Wesenheiten zum Objekt, die juristischen Welt ist eine Gedankenwelt, die zu der Welt des realen Geschehens sich ähnlich verhält, wie die Welt der ästetischen Empfindung zu der theoretischen Erkenntnis. Sie ist eine Welt der Abstraktionen." JeLLINEK, Georg: System der subjektiven öffentlichen Rechte. Freiburg, Akademische Verlagsbuchhandlung, J. C. B. Mohr, $1892,16$.

27 JeLlineK (1892): i. m., 14.

28 JeLLINEK (1892): i. $m$., 15.

29 JeLLINEK (1892): i. m., 15.

30 JellineK (1994): i. m., 41.

31 JeLLINEK (1994): i. m., 42.

32 Az empirikus típus fogalma „a jelenségek jellemző ismérveinek olyan összefoglalását jelenti, amely teljesen a kutató által elfoglalt állásponttól függ. Az így értelmezett típus rendezi a jelenségek sokféleségét, amenynyiben logikailag kiemeli belölük a közöset. A típus a kutató fejében lejátszódó absztrakció útján jön létre, amivel szemben áll a jelenségek szakadatlan sorozata - mint valóság. Az államról szóló tudomány feladata tehát az, hogy feltárja az állami viszonyoknak ezeket az empirikus típusait.” JELLINEK (1994): i. m., 46. 
valamilyen önkényes fogalomalkotásról van szó, hanem olyanról, amely a meghatározott tényekkel összefüggésbe hozható. ${ }^{33}$

Milyen hatással vannak az empirikus feltételek a normatív elvárásokra? Jellinek, ha nem is fogadja el az állam egy már eleve adott fogalmát, abból indul ki, hogy az állam egy reális adottság. De ahogyan a későbbi fejtegetésekből kiderül, a fogalom és a tárgy viszonya nem elég világos. Egyfelől egy egységes tárgyról beszél, és nem zárja ki annak a lehetőségét sem, hogy ez elméletileg megismerhető, de azt is hangsúlyozza, hogy ennek a tárgynak a teljes megismerése nem feladata a jogi megismerésnek. Az állam jogi fogalmát elválasztja a tárgytól, amely továbbra is a "Sein" világához tartozik. A fogalom nem adja vissza a megismerésre váró tárgyat, hanem csupán egy eszköze a megismerésnek. Talán akkor értjük meg legjobban Jellinek módszertani törekvéseit, ha azt mondjuk, Jellinek az állam jogi fogalmát az állam mint olyan (Ding an sich) fogalmától választja el. ${ }^{34}$

Jellinek a fogalom és a tárgy közötti hiátust a célmeghatározás kritériumával próbálja meg áthidalni. Ez azonban nem mentes az ellentmondásoktól. Annak ellenére, hogy Jellinek azt vallja, nem lehetséges abszolút megismerés, arról beszél, hogy az emberek között létrejöhet egy pszichológiai értelemben vett egység a közösen követendő célokról, amely alapján az állam mint egység elgondolható. ${ }^{35}$ Jellinek szerint a normatív és az empirikus közötti kapcsolatot a cél fogalmának kellene megteremtenie. A jogi jelenségek jobb megértésére „a célok változása tanít bennünket meg”. ${ }^{36}$ A létezés ugyanis Jellinek szerint alapjában véve semmi más, mint tervszerüen összehangolt emberi akarati akciók összessége. ${ }^{37} \mathrm{Az}$ állam is „emberek sokaságának akarati viszonyaiból áll, vagyis az állam végső összetevői az uralmon lévők és az uralom alatt állók akarati viszonyai. Ezek a viszonyok azonos jellegűek és magasabb fogalmak alá rendelhetők, ezért meg kell keresni az államot alkotó akarati viszonyok egységesítő elvét. [...] Ez az egység nem pusztán területi, időbeli, kauzális vagy formális jellegü, hanem teleológiai egység. Emberek sokaságát a tudatukban egyesíti, ha őket állandó és belsőleg koherens célok kapcsolják össze egymással. Minél intenzívebbek ezek a célok, annál erősebben nyilvánul meg az állam egysége, amely kifelé egy szervezet, azaz olyan személyek révén is kifejeződik, akik arra hivatottak, hogy az egységesítő célmozzanatokról saját tevékenységükkel gondoskodjanak. Az ilyen szervezett, emberekből álló célegységeket nevezi Jellinek szövetségegységnek."38 Az állam cél-egység elképzelése és az emberi magatartások végtelen sokféleségé-

33 LePSIUS: i. m., 322

LEPsius: i. m., 315.

LePsius: $i$. m., 315.

JELLINEK (1994): i. m., 51.

JELLINEK (1994): i. m., 54.

38 Szilágy Péter: Előszó. In: Jellinek (1994): i. m., 15. „Der Staat ist eine Zweckeinheit. Daher muss die soziale Staatslehre, die von solcher Staatsauffassung ausgeht, die Zwecke nachwiesen, die uns die im Staate vereinigte Vielheit als Einheit erscheinen lässt. Das Dasein solcher Zwecke ergiebt sich aus der unwidersprechlichen psychologischen Tatsache, dass das Leben des Staates in einer ununterbrochenen Reihenfolge menschlicher Handlungen besteht, jede Handlung aber notwendig durch ein Motiv, also durch einen Zweck bestimmt ist." JELLINEK, Georg: Allgemeine Staatslehre. Berlin, Verlag von O. Häring, 1914², 234. 
nek ismeretelméleti premisszája azonban meglehetős feszültségben vannak egymással.

Azt, hogy miképpen kapcsolódik össze a normatív és az empirikus látásmód, a tények normatív erejének konstrukciója mutatja meg igazán. Jellinek felfogása szerint bizonyos feltételek mellett a tényleges, faktikus állapotok is normativitással rendelkeznek. A „faktikus” az ember azon lélektani adottságához tartozik, amely azt nemcsak tényként fogadja el, hanem a megítélést megalapozó normaként is tekint rá. A faktikus tehát, amely normatív erővel hat, nem egyenlő a létezővel. A ténylegesség normatív ereje végső soron az ember kognitív problémájának a kifejeződése, az a világ, amelyet mint akaratot nem lehet a tényektől elválasztani. ${ }^{39} \mathrm{Ez}$ ahhoz a meggyőződéshez kapcsolódik, amely alapján meghatározott ténylegesen fennálló viszonyokat jogilag elismerhetőnek gondolunk, egy emberi megismerési aktus, amely a normatív erőről dönt. A „faktikus”, mint egyfajta szubjektív előfeltevés, éppen ezért sohasem lehet a priori. ${ }^{40}$

A tényszerüség normatív erejének az alapja nem a tényleges állapotok ésszerüségének a belátása, hanem az emberi természetnek az a tovább vissza nem vezethető tulajdonsága, hogy a már megszokottat fiziológiailag és pszichológiailag is könynyebben tudja reprodukálni, mint az újat. ${ }^{41}$ Jellinek szerint eredetileg a jog sohasem volt más, mint tényleges gyakorlat, majd ennek a gyakorlatnak a tartóssága hozta létre azt az elképzelést, amelynek alapján maga a gyakorlat jelent meg a közösség autoritással bíró parancsaként, vagyis jogként. ${ }^{42}$

Az állami berendezkedésnek jogrenddé való átalakulása tehát két pszichológiai összetevő hatására vezethető vissza. Az egyik, a konzervatív tényező a tényleges gyakorlat normatívvá alakítása, a másik, a progresszív pedig a pozitív jog fölött áló jog gondolatának elfogadása formájában hat. Ez a két mozzanat azonban a jogfejlödés folyamatában szükségképpen összekapcsolódik, ezért az egyoldalú felfogások többnyire történelmileg igen rövid időszakokra korlátozódnak. Az emberek tudatában az állam nemcsak mint tényleges, hanem mint jogszerủ és egyben ésszerủ hatalom jelenik meg, ami azt a meggyőződést táplálja, hogy az állami rend azonos a jogrenddel. Ebből az is következik, hogy különbséget kell tenni az államélet valóságos folyamatai és az államjogi normák között. A tényleges viszonyok időben mindig megelőzik az általuk előidézett normákat, ezért vannak olyan időszakok, amikor az állami rend tisztán tényleges hatalomként jelenik meg, és csak később nyer jogi jelleget. ${ }^{43} \mathrm{Az}$

39 LePsiUs: i. m., 315-317.

40 Lepsius: $i$. m., 317.

41 „Der Grund der normativen Kraft des Faktischen in seiner bewussten oder unbewussten Vernünftigkeit zu suchen, wäre ganz verkehrt. Das Tatsächliche kann später rationalisiert werden, seine normative Bedeutung liegt aber in der weiter nicht ableibaren Eigenschaft unserer Natur, Kraft welcher das bereits Geübte physiologisch und psychologisch leichter reproducirbar ist als Neue." JeLLINEK (1914): i. m., 338.

42 „Alles Recht in einem Volke ist urspünglich nichts als faktische Übung. Die fortdauernde Übung erzeugt die Vorstellung des Normmässigen diese Übung und es erscheint damit die Norm selbst als autoritäres Gebot des Gemeinwesens, also als Rechtsnorm.” JeLLINEK (1914): i. m., 339.

43 „Die Möglichkeit solcher gänzlich ausserhalb des Rechtsgebietes stehender Vorgänge kann daher niemals durch Gesetze gänzlich ausgeschlossen werden, und selbst bei einer reich entwickelten Rechtsordnung können »Verfassungslücken« vorkommen, die gegebenen Falles durch die faktischen Machtverhältnisse ausgefüllt werden." JELLINEK (1914): i. m., 359. 
államok jogszabályokba foglalt írott alkotmányát ugyanis meg kell különböztetnünk tényleges alkotmányuktól, amely a hatalom valóságos megoszlásában és az erre épülő jogrend érvényességében fejeződik ki. ${ }^{44}$ A legfelső állami szervek közötti hatalmi egyensúly megváltozása esetén az új viszonyok akkor is elkerülhetetlenül kifejeződnek a valóságos kapcsolatokban és intézményekben, ha az alkotmánynak egyetlen betüje sem változik meg, mint ahogyan azt az angol parlamentáris kormányforma kialakulása is mutatja.

$A z$ állam létezésének ténye tehát a jog számára áthághatatlan korlátot jelent. $A z$ államélet alapjaiban bekövetkezett változás megsemmisítheti az adott jogot, de a jog sohasem rendelkezik azzal a hatalommal, hogy kritikus időszakokban meghatározza az államélet menetét. Fejlett jogrendszerekben is előfordulhatnak alkotmányhézagok, amelyeket a tényleges hatalmi viszonyok töltenek ki. ${ }^{45}$ De ez nem jelenti azt, hogy a „faktikus” fenti értelmezésével Jellinek végső soron a jogi kereteket figyelmen kívül hagyó hatalmi állam teoretikusa lenne. ${ }^{46} \mathrm{~A}$,faktikus” ugyanis nem egyenlő a mindig adottal, hanem egy elképzelés, egy meggyőződés a fennálló rend normatív erejéről. A normativitás egy olyan elképzelését foglalja magában, amely szerint egy norma nem lehet csupán valami külsődleges, és szorosan kapcsolódik ahhoz, amit az egyének a normák elismerhetőségéröl gondolnak. ${ }^{47}$

Továbbra sem világos azonban, hogy miképpen lesz az egyéni akaratokból egy kollektív, közösségi akarat. ${ }^{48}$ Az állam egy egység. Ahhoz, hogy ez az egység előálljon, szükség van olyan eljárásokra, ahol a célelképzeléseket ki lehet nyilvánítani és ezek közül a megfelelőt ki lehet választani. Azt lehet mondani, hogy itt lehetne a helye Jellinek elméletében egy képviseletelméletnek vagy egy parlamentarizmusfelfogásnak.

Minden szövetségnek, így az államnak is egységes akaratra van szüksége. Az állam egy egységes, szervezett szövetség. A hangsúly most a szervezetten van. Az állami szervek nemcsak a szövetség egységét, hanem az állam cselekvési képességét is biztosítják. ${ }^{49}$ Ebben az államfelfogásban kulcsfontosságú, hogy milyen szer-

44 „Die Lehre vom Staate empfängt nun durch die grundlegende Erkenntnis der normativen Bedeutung des faktischen hervorragendste Förderung. Durch sie erst wird begründet und verständlich, was die soziale Theorie von dem Verhältnis von Staat und Gesellschaft behauptet hat. Ihr zufolge ist ja die Staatsordnung ein fortwährender Kompromiss der einzelnen um die Herrschaft ringenden Gruppen und auch die Verfassung des Staates in Wahrheit nichts anderes als das Spannungsverhältnis der gesellschaftlichen Faktoren. Man müsse zwischen der geschriebenen und der tätsachlichen Verfassung eines Staates unterscheiden. Die letztere, in welcher das wirkliche Leben des Staates zum Ausdruck kommt, bestehe in der faktischen Machtverteilung, die in jedem Staate unabhängig von geschriebenen Rechtsätzen vorhanden ist." JELLINEK (1914): i. m., 341.

45 „Das Dogma der Geschlossenheit des Rechtssystems verkennt das Grundverhältniss von Recht und Staat. An dem Faktum der staatlichen Existenz hat alles Recht seine unübersteigliche Schranke. Daher kann eine Änderung in den Grundlagen des staatlichen Lebens zwar vernichten, dem Recht wohnt aber niemals die Macht inne, den Gang des Staatslebens in kritischen Zeiten zu bestimmen. Um eklatante Verletzungen des Staatsordnung zu beschönigen, hat man die Kategorie des Staatsnotrechtes angewendet, die doch nur ein anderer Ausdruck für den Satz ist, dass Macht vor Recht geht." JELLINEK (1914): i. m., 358.

46 LePsiUs: $i$. m., 324.

47 Lepsius: i. m., 326.

48 LePsius: $i$. m., 327.

49 JELLINEK (1914): i. m., 540. 
vek minősülnek az állam szerveinek. Ez a kérdés már Gerber és Laband elméletének is a fundamentumát jelentette. A kérdés tétje természetesen a parlament jogállása. A korszak politikai küzdelmeit a parlament politikai befolyásáról folytatott vita határozta meg, a parlament elhelyezése az államelméleti konstrukcióban kiemelt politikai jelentőséggel bírt. Laband ebben a kérdésben nagyon világos állásponttal rendelkezett: a parlament nem állami szerv. Jellinek tisztában volt vele, hogy a társadalmi mozgalmak az állam demokratizálása felé hatnak. Nem értett egyet Laband mély konzervativizmusával, és a parlament jelentőségének nagyobb súlyt adó fogalmi megoldást keresett. Ez azonban nem volt egyszerü, ugyanis a monarchikus elv szupremáciáját kellett volna valahogyan összehangolni a népképviselet elvével.

Ebben a fogalmi nyelvben az állam szervei egyben az állam hatalmának hordozói is. Jellinek elméletében, hasonlóan Gerberhez és Labandhoz, az állam személyisége egy olyan hatalmi akaratot jelent, amely nincs alávetve más hatalomnak. Ennek a legföbb hatalmi akaratnak a hordozója az uralkodó, mint az állam legföbb szerve. Az állam személyisége tehát az egységes hatalmi, akarati központként elgondolt állam fizikai megszemélyesítője. Jellinek továbbra is fenntartotta azt a fogalmi nyelvezetet, amelyben a dogmatika funkciója továbbra is az államhatalom igazolási kérdéseinek a semlegesítése. Az állam „hordozója” és az „egy legföbb szerv” azonossága fényében csak a monarchikus állam lehetett az egyetlen „reális” lehetőség.

Az állam szervei mögött tehát nincs más személy, csak az akarattal rendelkező állam maga. Az akarattal pedig az állam csak szervezetein keresztül rendelkezik, csak a szervezetein keresztül képes cselekedni. Ezért mondja azt Jellinek, hogy „az állam egy akaró és cselekvő egység". Jellinek távolodását a konzervatívoktól az jelezte, hogy kész volt az uralkodó mellett a népet és a parlamentet is államszervként elismerni. Ebben az eredendően a monarchikus-bürokratikus állam igazolására fazonírozott dogmatikai nyelvezetben azonban ez a szándék számos ellentmondáshoz vezetett.

Jellinek nem értett egyet azzal, hogy az állam és az államhatalom egységéböl az következne, hogy az államot csak egy állami szerv jelenítheti meg. Az állam fogalmának a meghatározása során az állam két fontos alkotóelemét különböztette meg. Az állam egyfelöl az egyének akaratát közös célok által összefogni képes „szövetségegység", másfelöl pedig egy hatalmat gyakorló uralmi szervezet. Ez azonban nem jelenti azt, hogy az államon egyfajta politikai közösséget kellene érteni, amely önmaga kormányzására hoz létre uralmi szerveket. A szövetség egységébe forrt akarati viszonyok ugyanis alapvetően uralmi viszonyok. Az állam erőhatalmat gyakorol. Megvan az a képessége - és neki van csak ilyen a szövetségen belül -, hogy akaratát feltétel nélkül mások akaratára átvigye. A hatalom érvényesítésének ez a képessége az állam legfontosabb jellemzője, e nélkül nem lehet az államot elképzelni. ${ }^{50} \mathrm{Ez}$ az erőhatalom különbözteti meg az államot a politikai közösség kategóriájától. Jellinek hangsúlyozza, hogy a politikai közösség vagy azonos az állammal, vagy az állam által uralt közösség. A „politikai” mindig egyben „államit” is jelent. A „politikai” fogalma az állam fogalmában már benne foglaltatik. ${ }^{51} \mathrm{Az}$ államban minden hatalom csak ma-

50 JeLLINEK (1914): i. m., 180.

51 JeLLINEK (1914): i. m., 180. 
gától az államtól indulhat ki. „Az állam eredeti uralkodóhatalma alakítja ki a tartósan megtelepedett emberek szövetség-egységét." 52

Miért van szükség az állam és az államszervek viszonyának újragondolására? $S$ miképpen kapcsolódik ez a népképviselet elvéhez? Jellinek az államszervek között különböző kategóriákat különböztet meg. A legalapvetöbb megkülönböztetést a közvetlen és a közvetett szerv jelenti. A közvetlen állami szervet a szövetségegység kialakulásakor hozzák létre. ${ }^{53}$ Ma azt mondanánk erre, hogy a közvetlen állami szerv az, amelyet az alkotmány hoz létre. Az uralkodó és a parlament általában ilyen közvetlen szerv. A közvetlen szervek egy sajátos alesetét képezik az ún. felhatalmazó szervek (Kreationsorgane), ${ }^{54}$ amelyek egy jogilag meghatározott eljárásban egy másik szervet hozhatnak létre. Ebben az értelemben a felhatalmazó szerv az állam materiális alapjaihoz tartozik, mint például egy választási monarchiában a királyválasztó gyülés vagy a pápaválasztó bíborosi kollégium.$^{55}$ Egy további kategóriát jelent az elsődleges és a másodlagos szerv közötti különbségtétel, amely nagyon hasonló az előbb említett felhatalmazó és felhatalmazott szerv viszonyához. Az elsődleges szerv közvetlenül reprezentálja az államot, míg a másodlagos szerv csak az elsődleges felhatalmazása alapján. A parlament státusza megítélésének szempontjából releváns még az önálló és az önállótlan szerv megkülönböztetése. Ez alapján az önálló szerv rendelkezik egyfajta akaratképességgel, az önállótlan nem, mégis fontos szerepet tölt be, ugyanis az önálló szerv akarata csak az önállótlan szerv közremüködésével emelkedik jogeröre. A fenti tipológia alapján az uralkodó egy közvetlen, elsődleges és önáló állami szervnek minősül, a parlament pedig egy közvetlen, másodlagos és önállótlan szervnek. A végeredmény az, hogy bár a parlament is állami szerv, a legföbb szervnek az uralkodó számít.

A végeredmény nem volt kétséges, a választott fogalmi büvészkedés pedig meglehetősen önkényesnek tünik. Maga az állami szervek tana nem visz közelebb annak a megértéséhez, hogy mi a szerepe a parlamentnek és a népképviselet elvének Jellinek elméletében. Érdemes tehát másfelöl közelíteni. Jellinek szerint ugyanis a nép is egyfajta állami szerv. Miképpen kapcsolódik egymáshoz a nép, a parlament és az állam?

Jellinek álláspontjának az az alapja, hogy az állam és a nép egy és ugyanaz. Az állam egyfelöl a hatalom alanya, másfelöl pedig a nép közös érdekeit igazgatja. Az államnak ez a két oldala egy sajátos kapcsolatot létesít egymással, ezt fejezi ki az állam önkötelezésének az elve. Az „önkötelezés” azt jelenti, hogy az állam „hatalmat gyakorló” szubjektuma elkötelezi magát a közösség érdekeit képviselő „énje” iránt is. Az államhatalom hordozója aláveti magát azoknak a törvényeknek, amelyeket maga alkotott. ${ }^{56}$

Ez a konstrukció hivatott igazolni azt is, hogy miért lehet egyáltalán jognak tekinteni az államszervezeti jogot. A Laband-féle formális törvények, amelyek normatív

52 JeLLINEK (1914): i. m., 180-181.

53 JELLINEK (1914): i. m., 544-545.

54 JELLINEK (1914): i. m., 545.

55 JELLINEK (1914): i. m., 545.

56 JeLLINEK (1914): i. m., 369. 
ereje nem volt tisztázott, az államszervezeti normák jogszerúségét nem tudták megalapozni. De Jellinek nemcsak az államszervezeti normák jogszerüségét alapozza erre a tanra, hanem a szubjektív alanyi közjogok elismerését is. A hatalmi állam és a közös érdekeket megjelenítő állam szembeálításával rá lehet mutatni ezekre a jogokra, amelyeket az állam adományoz a polgárainak, és kötelezettséget vállal tiszteletben tartásukra. Ennek a konstrukciónak az a sajátossága, hogy úgy ismer el bizonyos alapvető jogokat, hogy az államot mint adottságot elismeri. Az állam egy magától értetődően létező szubjektum, amely saját hatalmát korlátozva alanyi közjogokat adományoz.

A parlament helyzetének néhány vonatkozását az „önkötelezésnek” ez a konstrukciója is meg tudja világítani. A parlament a közös célok meghatározásában vesz részt, a törvényalkotási eljárásban biztosított beleegyezési jogával pedig az állami akarat egy külső korlátját jelenti, a törvényekben biztosított alapvető jogok védelmezője, az állam önkorlátozásra tett ígéreteit kéri számon. A legfőbb állami szerv „önkötelezésének" bizonytalanságaiból fakadó politikai konfliktusokat is a parlamentnek kell felvállalnia. A parlament és az uralkodó politikai konfliktusában tovább öröklődnek az állam és a nép szembeállításának labandi törekvései. Mindezzel együtt el kell ismerni, hogy a parlament államszervvé nyilvánításával Jellinek az állam egyfajta demokratizálásának kívánt volna utat nyitni, de meglehetősen kétséges, hogy járható utat választott, hiszen ebben a konstrukcióban már a parlament is része volt az eddig csak az uralkodó által dominált állam fogalmának.

Jellinek szándékai talán már világosabban rajzolódnak ki, de a népképviselet elvének a tartalmáról még nem sokat tudunk. Gerbernél és Labandnál a népet az állam személyesítette meg. Jellineknél a nép már egy állami szerv (!), méghozzá egy felhatalmazó szerv (Kreationsorgan). ${ }^{57}$ Gerbernél és Labandnál állami szerv csak az lehetett, amely az állami akarat kinyilvánításában közremüködik, Jellineknél pedig már azok is, amelyek közremüködnek egy szerv létrehozatalában. Vagyis a közvetlen állami szerv kategóriáját kiterjesztette a felhatalmazó szervekre is.

Milyen értelemben reprezentál egy felhatalmazó szerv? Jellinek hangsúlyozza, hogy itt nem arról van szó, mint a pápaválasztó bíborosi kollégium esetében, ahol a bíborosok választják a pápát, de a pápa nem a bíborosokat képviseli, hanem az egész egyházat. A nép nem ilyen értelemben felhatalmazó szerv. Ebben az esetben a képviselök a szavazókat képviselik. Ezért ez a képviseleti szerv a közösség (Körperschaft) tagjaihoz is hozzátartozik, a szerv által kinyilvánított akarat a közösség tagjainak is az akaratát jelenti ${ }^{58} \mathrm{~A}$ fent részletezett tipológiát felhasználva: a parlament egy másodlagos és közvetett állami szerv, amely közremüködik az állami akarat kinyilvánításában, a nép pedig, amely a parlament tagjait megválasztja, egyfajta közvetlen „felhatalmazó szerv”. A parlament a népet reprezentálja, amely őt megválasztotta.

Miért volt szükség az állami szervek ilyen megkettőzésére? Mi értelme van annak, hogy a nép és a parlament is államszerv? Ez különösen annak fényében érdekes kérdés, hogy Jellinek nem volt jó véleménnyel a parlament képviseleti teljesítményéröl. A parlamentarista államokat nem tartotta követendő példának. „Az angolok csak egy

57 JeLLINEK (1914): i. m., 581.

58 JeLLINEK (1914): i. m., 585. 
pillanatra szabadok, hogy aztán újra rabszolgák legyenek." ${ }^{59}$ Ehelyett a népképviselet fogalmát inkább a közvetlen demokráciához kapcsolta. Egy olyan keretben tud a nép és a népképviselet jogi egységet képezni, ahol a képviselök ténylegesen függenek a választóiktól. Ebben az esetben a parlament az a szerv lehet, amelyen keresztül a nép ki tudja nyilvánítani az akaratát. A parlamentarizmussal szemben még a hivatásrendi képviselet gondolatát is igazolhatóbbnak tartotta. ${ }^{60}$ Különösen a franciák voltak érzékenyek erre a sajátos etatista képviselet-felfogásra. Carre Mallberg kritikája szerint az államot vagy a néptöl elválasztva gondoljuk el, mint Laband, vagy pedig a nép megszemélyesítőjének tekintjük, ahogyan a francia nemzeti szuverenitás gondolatából fakad. Az a harmadik út, amit Jellinek keres, nem létezik. ${ }^{61}$

Az egyik lehetséges magyarázat Jellinek parlamentarizmusfelfogására, hogy Jellinek a parlamentarizmus erősítését és egy parlamentáris rendszer bevezetését nem tartotta reális politikai lehetőségnek. ${ }^{62}$ Jellinek szerint a parlamentáris rendszer erősítésének a legfőbb akadálya maga a porosz dominancián alapuló birodalmi alkotmány intézményes struktúrája. A birodalmi gyülés súlyának megnövelése a porosz érdekekkel ellentétes. A parlamentáris jelleg csak azon az áron erősíthető, ha visszaszorítják a porosz állam meghatározó szerepét a birodalom működtetésében. A birodalmi kancellár és a porosz államminiszter megkettőzése komoly belső feszültségekhez vezetne, a birodalmi gyülés és a porosz képviselőház dualizmusát erősítené. Ezzel összefüggésben a parlamentarizmus erösítése azt jelentené, hogy a szövetségi tanács eddig ellenőrzés nélkül gyakorolt hatáskörei parlamenti ellenőrzés alá kerülnének. Emellett a tagállamok befolyását is csökkentené, nem beszélve a poroszok befolyásáról. Jellinek ellenérve ennél általánosabb: azt állítja, hogy a parlamentarizmus csak egységes unitárius államban elgondolható. A poroszok sajátos helyzete a birodalom föderális struktúrájában a parlamentarizmust lehetetlenné teszi. ${ }^{63}$ A parlamentarizmus másik lényeges akadálya a német pártrendszer sajátosságából következik. Nincsenek ugyanis hagyományos pártok - kormányképesek sem -, csak szétaprózódott, regionális befolyással rendelkező pártok müködnek. Ezek a pártok a kormányzatot akarják hatalmukban tartani, de nem akarnak kormányozni. A nagyobb pártok ennek tetejébe nem is akarják a parlamentarizmust, regionális hatalmukat és a fennálló struktúrában meglévő befolyásolóképességüket akarják inkább stabilizálni. ${ }^{64}$

59 JELLINEK (1914): i. m., 581.

60 SchönBerger, Christoph: Das Parlament im Anstaltsstaat. Frankfurt am Main, Vittorio Klostermann, 1997, 248-252.

61 SchönBeRger (1997): i. $m$, 252-254.

62 Lásd erröl JeLLINEK, Georg: Bundesstaat und parlamentarische Regierung. In: Uő: Ausgewählte Schriften und Reden, Bd. 2. Berlin, 1911, 439-447.; JeLLINEK, Georg: Regierung und Parlament in Deutschland. Geschichtliche Entwicklung ihres Verhältnisses. Vortrag gehalten in der Gehe-Stiftung zu Dresden am 13. März 1909. Leipzig, 1909. Lásd még: Schönberger (1997): i. m., 257-267.; Kopp, Dieter: Jellineks Parlamentarismus- und Parteianalyse „auf der Grenzlinie von Staatsrecht und Politik”. In: AnTER, Andreas (Hrsg.): Die normative Kraft des Faktischen. Das Staatsverständnis Georg Jellineks. Baden-Baden, Nomos, 2004, $125-129$.

63 JeLLINEK (1911): i. m., 446.

64 JeLlinek (1911): i. m., 447.; SchönBeRger (1997): i. m., 265. 


\section{3. Államtan és politika}

Az államjogtan és a politika viszonya Jellinek egyik központi témája. Különösen a császárság alkotmányos közéletében bekövetkezett változások ösztönözték arra, hogy újra és újra végiggondolja a közjog és a politika viszonyát. Jellinek is tisztában volt azzal, hogy a közjog politikai alapjait az alkotmányos rend képezi. A kérdése inkább az volt, hogy az alkotmányos rendre kiható politikai változásokat miként lehet a közjogtudomány módszereivel megragadni, legyen szó a politikai kisebbség alkotmányos jogainak az értelmezéséről ${ }^{65}$ vagy az alkotmányos átalakulások jogi értelmezéséről. ${ }^{66}$ Ennek a nehézsége elsősorban abban rejlik, hogy a közjogban a kormányzat és a parlament viszonya nemcsak jogi, hanem hatalmi kérdés is ${ }^{67} \mathrm{~A}$ politikai szereplők tényleges befolyásolóképességének a nyomai az intézményes struktúrán is meglátszanak.

Ennek a problémának a megragadására törekedett Jellinek az alkotmánymódosítás (Verfassungsänderung) és az alkotmányos átalakulás (Verfassungswandlung) megkülönböztetésével is. Alkotmánymódosítás alatt Jellinek azt értette, amikor az alkotmány szövegét megváltoztatják, és ennek következtében módosul az alkotmányos rend. Az alkotmányos átalakulás esetében az alkotmány szövege változatlan marad, de bizonyos tények az alkotmányos rend módosulását okozzák. ${ }^{68}$ Jellinek fogalmi megkülönböztetése mögött a Német Császárság elsősorban hatalompolitikai okok miatt megváltozott alkotmányos viszonyai álltak. Ezek a megváltozott feltételek II. Vilmos trónra lépéséhez kapcsolódtak. Az új császár egy új alkotmányos nyelvezetet is hozott magával: a feudális, patrimonális állam iránti nosztalgiát. Megszünt az a birodalom alapításakor még általános konszenzus, hogy az új szövetségi állam a feudális-patrimonális keretek meghaladására épül. A jogászi módszerre épülö közjogi dogmatika Laband vezetésével az alkotmányos rendet egy olyan centralizált, a jog által koordinált bürokratikus államként értelmezte, amely nem ismerte el a régi feudális kiváltságokat az állam hatalmával szemben. Ez akkoriban egy viszonylag progresszív felfogásnak számított, amely az alkotmányosság és az állam olyan eszményére épült, amely elutasította a patrimonális uralmi viszonyok létjogosultságát. Jellinek világosan látta, hogy a labandi közjogi dogmatikának csak a tételes jog értelmezésére és magyarázatára irányuló módszere az alkotmányos rend jól kivehető és sokak által vitatott felfogásán alapult. Könnyen beazonosítható alkotmánypolitikai álláspontja volt az unitarizmus és partikularizmus vitában, vagy éppen a parlament státuszával kapcsolatban. Jellinek szerint az alkotmányos közélet változásának az oka abban rejlett, hogy jött egy új generáció, amely az alkotmányos alapkérdésekröl másképp

65 Jellinek, Georg: Das Recht der Minoritäten. Wien, Alfred Hödler, 1898.

66 JelLinek, Georg: Verfassungsänderung und Verfassungswandlung. Berlin, Verlag von O. Häring, 1906.

67 „In jedem constitutionelle Staate steht in den Beziehungen zwischen Regierung und Parlament nicht nur Recht gegen Recht, sondern auch Macht gegen Macht. [...] Nicht anders aber ist die Stellung der parlamentarischen Minderheit zur Mehrheit. Ihre geschäschftsordnungsmässigen Rechte sind auch Machtmittel." JELLINEK (1898): i. m., 37.

68 JELLINEK (1906): i. m., 3. 
vélekedett, mint a bismarcki alapítók. ${ }^{69} \mathrm{~S}$ ezek az új eszmék nem alulról, hanem az állam fejének környezetéből, felülről érkeztek. Ezek a változások a közjogtudományt sem hagyták érintetlenül. A közjogtudomány előfeltételez egy elképzelést az alkotmányról. ${ }^{70}$ Olyan átalakulásokat kell a közjog művelőjének feldolgozni és értelmezni, amely meghaladja a labandi jogászi módszer kereteit.

Jellinek a következő példákat hozza fel az alkotmányos átalakulás jelenségeire. Az alkotmány szerint a Szövetségi Tanácsot (Bundesrat) a császár évente köteles összehívni, azonban a Szövetségi Tanács 1883-tól folyamatosan müködött, formálisan nem zárta be üléseit. ${ }^{71}$ A testület így is betöltötte az alkotmányos funkcióit, igaz, már nem teljesen az írott alkotmánynak megfelelően. Ennél sokkal jelentősebb változások történtek a birodalmi kancellár státuszában. A birodalmi kancellár három jól elkülöníthető státuszt jelentett: ő elnökölt a Szövetségi Tanácsban, a porosz állam meghatalmazottjaként tagja volt a Szövetségi Tanácsnak, és nem utolsósorban ő volt a császárnak felelős birodalmi miniszter. Az alkotmány szerint a Szövetségi Tanács ülésein a tanács tagjai, illetve meghatalmazott követei vehettek részt. Ebből következően a Szövetségi Tanácsban a kancellár csak mint a porosz állam képviselője szólalhatott fel. Bülow kancellár a politikai felelőtlenségét is erre hivatkozva hangoztatta, miközben általában birodalmi ügyekben szólalt fel mint a császár minisztere, és ilyen minőségében az alkotmány szerint nem kaphatott volna szót. ${ }^{72}$ Jellinek harmadik példája a birodalmi kancellár helyettesítésével kapcsolatos. A kancellár helyettesítéséröl szóló 1878-as törvény szerint a kancellár akadályoztatása esetén helyettes kinevezésére jogosult, aki a kancellárhoz hasonlóan ellenjegyzésre is jogosult.

69 „Die dogmatisch-juristische Schule der deutschen Staatsrechtswissenschaft hat es zwar unternommen, eine Lehre für das öffentliche Recht herauszubilden, die wie es dem Rechte ziemt, von dem Streit und Wandel politischer Anschauungen unberüht, die ruhende objektive Norm finden will. Die Gründung dieser Schule fiel zusammen mit dem Aufbau des deutschen Reiches. Das Gefühl, dass endlich nach langen Kampfen ein Ruhendes, Dauerndes, Bleibendes anstelle des alten politischen Wirrwarrs gesetzt worden sein, ihre Stimme in dem neuerbauten Tempel der objektiven rechtlichen Erkenntnis ertönen zu lassen. Aber auch ein weniger geübtes Auge hatte schon in jener klassischen Zeit in den Grundlehren der Meister den Gegensatz ganz bestimmter Parteianschauungen erblicken können. Unitarismus, Föderalismus und Partikularismus, Hoch- oder Minderschatzung parlamentarischer Machtbefugnisse und andere politische Wertmassstäbe werden an viele Probleme bewusst oder unbewusst herangebracht. Zudem war die Zeit, in der die juristische Behandlung des Staatsrechts entstand, die der Vorherrschaft liberaler Ideen und Parteien im Reich, was auch der Theorie im grossen und ganzen ein einheitliches Gepräge verleiht. Später wächst aber eine neue Generation heran, in deren politischen Anschaungen die grosse Wandlung sichtbar wird, die mit dem Jahre 1878 einsetzt und mit dem Thronwechsel im Jahre 1888 in neue Bahnen gelenk wird." JELLINEK, Georg: Der Kampf des alten mit dem neuen Recht. Heidelberg, Universitäts-Buchdruckerei von J. Hörning, 1907, 23.

70 „Von der Staatsrechtslehre Voraussetzungslosigkeit zu verlangen, ist ebenso Forderung einer unmöglichen Leistung wie jedes derartige ähnliche Ansinnen. Stets ist der Mensch selbst Vorausstzung seiner Forschung und dieser Mensch ist nicht denkbar als tabula rasa, die erst von dem Forscher beschrieben werden soll. Jedes Individuum kann nur in seiner Eigenschaft als Prudukt einer unendlichen Reihe von Kulturwirkungen an den von ihm zu erforschenden Stoff herantreten. So ist es denn auch natürlich, dass der Staatsrechslehrer nicht gänzlich ohne politische Meinungen sein kann, wenn er sein Wissensgebiet betritt. Wer vermöchte sich der Erfassung menschlicher Institutionen nach irgend einer Richtung hin zuzuwenden, wenn er ihnen nicht irgend welche Werte zuzuschreiben vermag!" JELLINEK (1907): i. m., 24.

71 JeLLINEK (1906): i. m., 22.

72 JeLLINEK (1906): i. m., 24-26. 
A szabályozásból a kancellár belátásán múló eseti helyettesítési gyakorlat következett volna, ezzel szemben a kancellár állandóan akadályoztatva van, és lényegében állandó - miniszterhez hasonló jogállású - államtitkárok segítségével működteti a birodalom közigazgatását. ${ }^{73} \mathrm{Ez}$ a fajta struktúra szintén nem az alkotmány szövegén alapul. A változások azonban egy irányba mutattak, a császári hatalom és a centralizáció erősödése felé.

Ezekre a gyakorlati problémákra is tekintettel Jellinek a politika két formáját különböztette meg. A politikát mint tudományt és a politikát mint gyakorlati bölcsességet, a politika múvészetét. A politika mint tudomány egyfajta kritikus nézőpont érvényesítését jelentette. A politika egyik általános megkülönböztető jegye, hogy jövőorientált, míg az államtan mint a létező tudománya a múltra és a jelenre irányul. A jövő felé irányultságnak azonban több megjelenési formája lehet, a jelenre és a múltra is kiterjedhet, hogy azokból a jövőre szóló tanulságokat vonjon le. „A politika a jelenre irányulva kritikai tan jelleget ölt, amely a létezőt - egy teleologikus szemlélettel nyert következtetések mércéje alapján - vagy megörzendőnek, vagy átalakíthatónak ítél."74 De a jövő felé tekintő kritikai nézőpont a múltat is felülvizsgálhatja. „Azok a kutatások, amelyek a periklészi demokráciának az athéni államelmélet tovább- vagy visszafejlődésére, vagy Sulla diktatúrájának a római köztársaság hanyatlására gyakorolt hatását vizsgálják, nem kevésbé politikai jellegűek, mint az a kísérlet, hogy az általános választójognak a Német Birodalom jövőbeli életére gyakorolt befolyását meghatározzuk. Ezért minden pragmatikus történelmi kutatás egyben politikai is."75

A politikai szempontok a társadalmi államtan számára is meghatározóak. „Mind a társadalmi államtan által vizsgálandó stabil államrend, mind pedig a jogrend szabályainak - amelyeket az államjogtannak kell kutatnia - mindenoldalú megismeréséhez kiegészítő politikai elméletre van szükség. A valóságban az állam állandó mozgásban van, amelyröl a társadalmi államtan és az államjogtan egyaránt csak pillanatfelvételeket ad. Az állam minden fontos életfolyamata és jogrendjének minden tétele azonban keletkezésük előtt és annak során politikai megfontolások és döntések tárgya volt, minden megvalósult állami cselekvés, minden fennálló jog politikai hatásokat vált ki. Ezért a minden politikai elemtöl való teljes elvonatkoztatás üres eredményekhez vagy legfeljebb az állam puszta vázának az ismeretéhez vezet, amelyből hiányzik az élö szervezet nyoma." ${ }^{76}$

Végül Jellinek arra is rámutat, hogy a politika az államjogtan számára is jelentős. Ugyanis „a politikai megismerés folyamatosan új jog iránti követelést teremt. Az ilyen követelés azonban föltételezi a fennálló jog alapos ismeretét. Ezért nagy jelentőségủ az államjogtan a politika számára, hiszen ez az előbbi nélkül feladatait nem tudja teljesíteni. A fennálló közjogi intézmények kritikája politikai feladat, amelyet az államjogtannak kell teljesítenie, mégpedig mind az általános és speciális, mind pedig az egyedi államjogtannak. A jogtudomány teljesen feladná hivatásának nemesebb részét,

73 JeLlinek (1906): i. m., 26-27.

74 JELLINEK (1994): i. m., 30-31.

75 JELLINEK (1994): i. m., 31.

76 JELLINEK (1994): i. m., 31. 
ha csak hátrafelé fordulna, és nem segítene abban, hogy a jövő hatalmainak elöre is utat nyisson." 77

Jens Kersten két maximában foglalta össze Jellinek politikához való viszonyát: (1) Nem lehet elfogadni olyan jogi konstrukciót, ami politikailag lehetetlen. (2) Feltételezni kell a legfőbb állami szervek cselekvéseinek a jogszerüségét. Az első maximának két oldala van. Egyfelöl a jognak nem szabad figyelmen kívül hagynia a politikai valóságot (empirikus dimenzió). Másfelöl vannak olyan jogpolitikai törekvések, amelyek politikailag lehetetlenek (normatív dimenzió). A második maximában foglalt vélelem akkor dől meg, amennyiben ténylegesen megállapítják a jogellenességet. A normatív helytelenség lehetősége nem elég. Amennyiben a jogsértést ténylegesen nem orvosolják, a jogsértés egy új jogot teremt. Ez a vélelem tehát különbözik a demokratikus jogállamokban uralkodó azon vélelmektöl, amelyek abból indulnak ki, hogy az állami szervek a demokratikusan hozott törvényeknek megfelelően cselekednek. ${ }^{78}$

Jellinek politikafelfogása tehát jól illeszkedik a tényleges normatív erejének és az állam önkötelezésének a doktrínáihoz. Maximái a hatalom jogi keretek közé szorításának egyfajta evolúciós elméletét formálták ki. Az államjog politikai hivatása, sajátos politikai-kritikai feladata ezt a fejlődést elősegíteni. Egy stabil jogrend megteremtése elsőrendü érdek. Mindehhez azonban az a belátás is hozzátartozik, hogy a jog sohasem tudja a politikai konfliktusokat teljesen jogi keretek közé szorítani. Igaz, a fejlődés világosan ebbe az irányba tart, egyre ritkábbak azok az alkotmányos konfliktusok, amelyeket nem jogi keretek között oldanak meg. Jellinek mai aktualitását is az alkotmánypolitikának ez az evolúciós felfogása adja: a közjog politikai küldetése az, hogy megteremtse és fenntartsa azt a fogalmi nyelvet, amely segítségével intézményes keretek között értelmezhetőek az alkotmányos konfliktusok. Az államtan így tud hozzájárulni a politika jogi keretek közé szorításához. ${ }^{79}$

\section{4. Összefoglalás}

Jellinek államelmélete a csak a pozitív jog értelmezésére koncentráló közjogi felfogás klasszikus kritikájának számít. Olyan kritikának, amely nem a válaszaival és a magyarázataival, hanem a máig nyitott kérdéseivel képes részévé válni az aktuális államelméleti vitáknak. Jellinek munkásságának újraértelmezését elméletének feloldhatatlannak tủnő ellentmondásai határozzák meg. Ezek közül a legalapvetőbbek az állam tényleges hatalmának és jogi korlátainak a viszonyából fakadnak. Jellinek ugyanis úgy próbálta meg visszacsempészni a német közjogi hagyományba a korlátozott hatalom eszméjét, hogy közben az állam tényleges hatalma korlátozhatatlanságának tézisét sem adta fel. Az állam fogalmát úgy próbálta meg a politikai közösség és a demokrácia eszméinek irányába nyitottabbá tenni, hogy közben az állam bürokratikus hatalomként való felfogását is megőrizte. A politikai közösséget Jellinek

\footnotetext{
JELLINEK (1994): i. m., 33.

78 KeRsten (2000): i. m., 200-201.

79 Kersten (2000): i. m., 205.
} 
egyfajta szövetségegységnek képzelte el. Az állam jogi személyiségének az elmélete és az állam szövetségegységként való felfogása között azonban feloldhatatlannak túnik a feszültség. Az egyik pólust az igazolási összefüggésektől mentesített állam fogalma jelzi, a másikat pedig a világos nyitás az igazolási összefüggések felé. ${ }^{80}$ Ezek az egymással ellentétes törekvések azonban nem egyenrangúak, a jellineki elméletben az állam hatalomelméleti felfogása megelőzi az állam jogi fogalmát.

Hiába tekinthető Jellinek államtana iskolateremtő munkának, államelmélete a módszertani kérdések tekintetében is alapvető kérdéseket hagyott megválaszolatlanul. Az általános államtan, az állam társadalmi és jogi oldala Jellineknél még valódi egységet képez, de ennek ára az, hogy Jellinek feláldozza a jogászi nézőpont önállóságát, végső soron az állam egy társadalmi elméletét alkotva meg. S az államtannak nem azt az elképzelését valósítja meg, amely esetleg képes a különböző diszciplínák közötti közvetítést felvállalni.

Azt, hogy Jellinek elmélete szándékai ellenére végül az állam társadalmi elméletévé vált, legjobban a szuverenitás értelmezésének problémája mutatja. Jellinek elméletében a szuverenitás problémája nem fordítható át a jogi érvényesség kérdésévé. Ezen a belátáson alapul lényegében Hans Kelsen kritikája is. Jellinek államelméletére nem tud ráépülni a pozitív jogot értelmező alkotmányelmélet. A ténylegesség normativitásának koncepciójából ugyanis nem következik a gyakorlat számára hasznosítható érvényességfelfogás és az ehhez kapcsolódó értelmezéselmélet. Az állam két oldalának az összekapcsolása végül csak az egyik oldal, a jog relativizálása árán sikerül.

Az önkötelezés elmélete, illetve az állam hatalomelméleti vagy szövetségegységként való felfogása a jogi keretek közé nem szorítható hatalmi állam tényén alapulnak, így nem képesek segíteni az alkotmányjogi értelmezések módszertani kérdéseiben, ahol az érvényesség problémájának világos megoldására van szükség. Jellinek elméletében így végül az államtan és a közjog közötti kapcsolat homályos marad. Nem világos ugyanis, hogy miképpen lehet egyesíteni a társadalmi és a jogi nézőpontot anélkül, hogy a jogtudomány önállóságát feladnánk. ${ }^{81}$ Mindebböl a jelenkori viták számára az a tanulság következhet, hogy az államelmélet csak mint a közjog háttérelmélete képes a joggyakorlat problémáihoz hozzájárulni.

\section{Abstract}

This paper makes an in-depth examination of the theory established by Georg Jellinek who - extending the perspective of the jurisprudence of state law based on legal methods - was concerned with issues of public law within the frames of general theory of the state. The author will demonstrate the claim that the special concepts of Jellinek's general and descriptive theory - like the „presupposition of factual validity” or the idea of the "state's self-obligation to law" - are the results of Jellinek's idea that there were no alternatives to the institutional system of the constitutional monarchy.

80 Möllers: $i$. m., 159-160.

81 MölleRs: i. m., 169-170. 